\title{
Stress Related to Pediatric Hospitalization and Possible Interventions: An Analysis of the Brazilian Literature
}

\author{
Kelly Ambrosio Silveira*, 1 \\ Orcid.org/0000-0002-2381-2322 \\ Kely Maria Pereira de Paula ${ }^{1}$ \\ Orcid.org/0000-0001-9095-6556 \\ Sônia Regina Fiorim Enumo ${ }^{2}$ \\ Orcid.org/0000-0001-9038-6151 \\ ${ }^{1}$ Universidade Federal do Espírito Santo, Vitória, ES, Brasil \\ ${ }^{2}$ Pontificia Universidade Católica de Campinas, Campinas, SP, Brasil
}

\begin{abstract}
Hospitalization may interfere with behavioral and emotional responses and influence outcomes in health and development. An analysis of the literature on the subject can contribute to the comprehension of stress triggers and their effects. This study reviewed the Brazilian literature on stress indicators associated with hospitalization in children and their caregivers. The methodological characteristics of each article, as well as their findings regarding stressful contexts, emotional and behavioral reactions and possible interventions were analyzed. A search for articles published between 2000-2016 was performed in the Virtual Health Library using the following keywords: child hospitalization, hospitalization, hospitalized child, stress, emotional stress and psychological stress. The application of inclusion and exclusion criteria resulted in a final sample of 38 articles. Most studies were concentrated in the Southeast, South and Northeast regions of the country, and relied on small and mixed samples. Few studies used assessment instruments. This review highlighted the need for interventions that improve communication in hospital settings. Initiatives that improve the quality of care, attend to families' needs, provide psychological support, and encourage play may also have beneficial effects on quality of life.
\end{abstract}

Keywords: Hospitalization, stress, child, caregivers.

\section{Estresse Relacionado à Hospitalização Pediátrica e Intervenções Possíveis: Análise da Literatura Brasileira}

\section{Resumo}

A hospitalização pode interferir em respostas comportamentais e emocionais e influenciar nos desfechos em saúde e no desenvolvimento. A análise da literatura sobre esse contexto pode ajudar na compreensão dos fatores desencadeadores e seus efeitos. Este estudo analisou a produção brasileira

* Mailing address: Av. Fernando Ferrari, 514, Goiabeiras, Vitória - ES, Brazil 29075-910. E-mail: kellyasfs@ gmail.com, kelymppaula@gmail.com and soniaenumo@gmail.com

Support: Fundação de Amparo à Pesquisa e Inovação do Espírito Santo; Coordenação de Aperfeiçoamento de Pessoal de Nível Superior. 
sobre indicadores de estresse relacionados à hospitalização em crianças e seus cuidadores. Foram analisadas características metodológicas e temas ligados a contextos estressantes, reações emocionais e comportamentais e possibilidades de intervenção. A busca na Biblioteca Virtual em Saúde, entre 2000-2016, com descritores hospitalização infantil, hospitalização, criança hospitalizada, estresse, estresse emocional e estresse psicológico indicou 38 artigos, após aplicação de critérios de inclusão e exclusão. As regiões Sudeste, Sul e Nordeste concentraram os estudos, feitos com amostras pequenas e mistas. Poucos utilizaram instrumentos avaliativos. Destacou-se a necessidade de ações que levem ao aprimoramento das comunicações nesse contexto, favoreçam o acolhimento, mantenham atenção às necessidades das famílias, tenham foco em atenção psicológica, e estimulem o lúdico para o incremento da qualidade de vida.

Palavras-chave: Hospitalização, estresse, criança, cuidadores.

\section{Estrés Relacionado con la Hospitalización Pediátrica e Intervenciones Posibles: Análisis de la Literatura Brasileña}

\section{Resumen}

La hospitalización puede interferir en respuestas conductuales y emocionales e influir en los resultados en salud y en desarrollo. El análisis de la literatura puede ayudar en la comprensión de los factores desencadenantes y sus efectos. Este estudio analizó la producción brasileña sobre estrés en la hospitalización de niños y sus cuidadores. Se analizaron características metodológicas y temas ligados a contextos estresantes, reacciones emocionales y comportamentales y posibilidades de intervenciones. Se realizó una búsqueda en la Biblioteca Virtual en Salud, en 2000-2016, con descriptores hospitalización infantil, hospitalización, niño hospitalizado, estrés, estrés emocional y estrés psicológico. Tras los criterios de inclusión y exclusión, se leen en su totalidad 38 artículos. Las regiones Sudeste, Sur y Nordeste concentraron los estudios, hechos con muestras pequeñas y mixtas. Pocos utilizaron instrumentos de evaluación. Se destacó la necesidad de acciones que lleven al perfeccionamiento de las comunicaciones, favorezcan la acogida, mantengan atención a las necesidades de las familias, tengan foco en atención psicológica, y estimulen el lúdico, para la calidad de vida.

Palavras clave: Hospitalización, estrés, niño, cuidadores.

Chronic illnesses in childhood and adolescence can interfere with behavioral, emotional, cognitive, physical and social aspects of development (Pinquart \& Shen, 2011), in addition to having a negative impact on academic performance (Pinquart \& Teubert, 2012). These problems can be aggravated by repeated hospitalization as well as negative experiences associated with hospital stays and procedures. Therefore, when caring for patients and their families, professionals should always consider the risk and protective factors which may increase or decrease the likelihood of negative health outcomes (Motta et al., 2015). Such efforts are especially important in developing countries (Kieling et al., 2011).
During hospitalization, individuals may be drawn away from the family environment and recreational activities, and placed in a context where they are submitted to unfamiliar and invasive procedures (Gomes, Fernandes, \& Nóbrega, 2016). According to these authors, the most frequent reactions to hospitalization include “. . . fear, anxiety, hyperactivity, impulsivity, agitation, insecurity, impotence, feelings of guilt, bodily injury or assault, feelings of abandonment and loneliness, nervousness, irritability, sadness, crying, and lack of concentration" (p. 886). Hospitalization may therefore have a disadvantageous effect on the child and their recovery (Price, Kassam-Adams, Alderfer, Christofferson, \& Kazak, 2016). 
These potentially traumatic events (stressors) and the accompanying stress responses are expected and typical features of illness and hospitalization, known to follow a normative developmental trajectory and occur across several pediatric conditions (Price et al., 2016). However, in some cases, the vulnerability to stress, clinical condition and characteristics of care may result in what is known as Pediatric Medical Traumatic Stress (PTMS). This condition was defined in 2003 by the National Child Traumatic Stress Network as ". . . a set of psychological and physiological responses of children and their families to pain, injury, serious illness, medical procedures, and invasive or frightening treatment experiences" (Price et al., 2016, p. 86). Stressors are defined from a transactional perspective of mutual influence between the person and their environment, according to the features of each stage of the life cycle. In the words of Grant et al. (2003), stressors are ". . . environmental events or chronic conditions that objectively threaten the physical and/or psychological health or wellbeing of individuals of a particular age in a particular society" (p. 449).

Early developmental stress can be toxic when associated with prolonged exposure to stressful environments in childhood without adequate social support. Toxic stress has longterm consequences for physical and mental development, as well as the neural architecture (Branco \& Linhares, 2018). The stress response can influence health outcomes by interfering with the transcription of genes responsible for inflammatory and immune responses (Slavich \& Cole, 2013). Its long-term effects on health may result from biological programming associated with stressful experiences during sensitive periods early in development, which may calibrate the way certain bodily systems will operate in the future, as per the Biological Embedding Model (Miller, Chen, \& Parker, 2011). The risks associated with these stressors may be especially serious in chronic illnesses, conditions associated with frequent or prolonged hospitalizations, or in the presence of psychosocial vulnerability (Linhares, 2016).
In addition to stress responses during the hospitalization itself, individuals may experience post-traumatic stress symptoms months or years after hospital discharge. This may be observed in both the child and their relatives depending on the intensity and duration of treatment, the threat of recurrence or complications in the long term, and the subjective perceptions of the situation. Post-traumatic symptoms include stress responses such as intrusive and recurrent recollections of events, avoidance of reminders of the trauma, as well as hyperarousal. This may increase reactivity and vulnerability to stress, interfering with the development of resilience (Price et al., 2016).

Since stress responses and reactions, and the ability to cope with them, result from the interaction of biological, psychological and sociocultural factors, which can also attenuate or exacerbate the challenges associated with treatment, it is also important to analyze the contextual variables related to hospitalization. According to this perspective, the social and personal resources available, as well as the assessment of the stressful situation, determine the coping strategy adopted, as result of the bidirectional influence between person and environment (Skinner \& Zimmer-Gembeck, 2016).

The individual coping strategies used by patients have an impact on quality of life and are influenced by features of their psychosocial development at different ages, as well as the type of illness and its characteristics (Carona, Silva, Moreira, Barros, \& Canavarro, 2014). The stress-coping process is structured around self- and co-regulation, both of which are associated with individual and interpersonal behavioral control strategies and contribute to risk or protection in different situations (Aldwin, 2011; Lansing \& Berg, 2014). Therefore, since the interaction with caregivers can influence children's emotional and behavioral reactions (Vivian et al., 2013), it is also important to investigate the difficulties perceived by family members in the context of illness and hospitalization (Xavier, Gomes, \& Salvador, 2014). 
Individual aspects of the relationship between stressors, stress responses, reactions and coping among children, adolescents and caregivers during hospitalization, as well as its impact on health, have been at least partially analyzed in the Brazilian literature. However, no literature reviews have focused on hospitalization stress, the theme of the present study. The description of existing research in the area will allow for the identification of assessment techniques, key variables and benefits of interventions implemented in these populations. Gaps in the literature might also be identified and contribute to the development of future studies. Such a review must span a considerable period in order to identify any changes in the types of studies conducted. As such, the present study consisted of a review of the national literature on indicators of hospitalization stress in pediatric care. The study analyzed the methodological characteristics of studies published over the course of 16 years (2000 to 2016), and discussed their findings regarding stressful contexts, emotional and behavioral reactions, and interventions for the well-being of patients and relatives.

\section{Method}

In August 2016, a literature search was conducted in order to identify studies developed in Brazil and published in journals included in databases associated with the Virtual Health Library/Biblioteca Virtual em Saúde (BVS). The BVS was established by the Pan-American Health Organization (PAHO) in 1998 as a technical cooperation platform, run by the LatinAmerican and Caribbean Center on Health Sciences Information/Centro Latino-Americano $e$ do Caribe de Informação em Ciências da Saude (BIREME). The BVS comprises the Virtual Health Library in Psychology (BVSPsi), which houses collections such as the Index Psi, providing full-text access to technical and scientific publications in Psychology, the Electronic Psychology Journals/Periódicos Eletrônicos em Psicologia (PePSIC), which includes a collection of scientific journals in
Psychology, as well as the Scientific Electronic Library Online (SciELO), which provides fulltext access to the contents of over 290 scientific journals from Brazil, Latin America, Portugal and Spain. The BVS was therefore considered an appropriate source for the present review.

The inclusion criteria were as follows: full-text availability; study published between 2000 and 2016; study conducted in Brazil; data collected at a hospital, from pediatric patients - children or adolescents - or accompanying adults; and presence of the term "stress" in the body of the text. Literature reviews and clinical trials and studies involving health professionals only were excluded.

Keywords were selected from the Health Sciences Descriptors/Descritores em Ciências da Saúde (DeCS), a thesaurus developed based on the Medical Subject Headings (MeSH) from the U.S. National Library of Medicine (NLM). These were entered into the search syntax as follows: [(stress or emotional stress or psychological stress) and (hospitalization or child hospitalization or hospitalized child)]. Results were filtered by year of publication, full text availability, type (article), and country of interest (Brazil).

A total of 373 articles were retrieved. After title screening to remove duplicates and publications which did not focus on the theme of this study, 125 articles remained. Abstract screening led to the exclusion of a further 60 articles which did not discuss hospitalization. Studies conducted in countries other than Brazil $(n=3)$ were excluded, as were 12 literature reviews and clinical trials, leaving 50 articles for additional screening. Seven of these dealt exclusively with stress in health care professionals and were therefore excluded from this review. Five did not include the words stress, stressor or stressful. The final sample therefore consisted of 38 articles. The search did not retrieve any theoretical studies which were similar to the present review.

Data were analyzed qualitatively and quantitatively. The year of publication, area of knowledge, geographical region where the study was conducted, and sample characteristics 
were entered into spreadsheets, together with other relevant methodological information. Sections of the articles which discussed stressors, emotional and behavioral reactions in patients and accompanying adults, as well as interventions, were also selected for qualitative analysis. This procedure was performed by two researchers who analyzed the representativeness of each section and their association with the topics of interest. The representativeness of each section was defined as the extent to which it represented the results or discussion of the article from which it was drawn. If one of the researchers found a section to be insufficiently representative, both would discuss whether to keep or discard it. The sections were organized in columns according to the following themes: Stressors, Emotional and Behavioral Reactions in patients and accompanying adults, and Interventions. This table was read several times as its contents were organized, and subcategories for the "Interventions" theme were proposed. At the end of data analysis, both researchers reviewed and confirmed the representativeness and adequacy of the sections drawn from the articles.

References marked with an asterisk indicate studies included in the review.

\section{Results}

Annual publication rates increased over time, as evidenced by the high correlation between the year of publication and number of articles published $($ rho $=.74)$. Seventeen articles were published between 2000 and 2010, while 21 were published between 2011 and 2016. Nursing $(n=21)$ and Psychology $(n=17)$ were the most heavily represented areas among the articles reviewed. Eighteen studies were conducted in Southern Brazil, 14 in the Southeast, while five studies were conducted in the Northeast region of the country. The majority of data collection took place in university hospitals and institutions specializing in child and adolescent health care (Table 1).

The most frequently discussed themes were the perceptions of patients and accompanying adults regarding the experience of hospitalization (36\% of articles), the structure or assessment of interventions (28\%) and the evaluation of stress symptoms and coping behaviors (21\%; Table 1).

The studies involved relatively small samples (1-20 participants $=61 \% ; 21-50$ participants $=21 \%$; over 50 participants $=15 \%$ ). Children and adolescents comprised the samples of 22 studies (57\%). The most frequently represented age groups were 6 to 7 and 11 to 12 years old (36\% of studies). Caregivers were evaluated in 12 studies (31\%). Four studies evaluated both patients and caregivers (Alcântara, Shioga, Lima, Lage, \& Maia, 2013; Carnier, Padovani, Perosa, \& Rodrigues, 2015; Jansen, Santos, \& Favero, 2010; Matsuda-Castro \& Linhares, 2014).

The samples included patients with varying clinical conditions who underwent several different procedures $(71 \%$ and $78 \%$ of studies, respectively; Table 1). Only eight studies recruited participants exclusively from oncology wards (Alcântara et al., 2013; Dias, Silva, Freire, \& Andrade, 2013; Hostert, Enumo, \& Loss, 2014; Hostert, Motta, \& Enumo, 2015; Menossi \& Lima, 2000; Motta \& Enumo, 2004a, 2004b, 2010). Two additional studies focused specifically on respiratory (Soares \& Bomtempo, 2004) and communicable diseases (Valladares \& Carvalho, 2006).

Some studies discussed stress symptoms associated with surgical and presurgical procedures (Broering \& Crepaldi, 2011; Carnier et al., 2015; Carnier, Rodrigues, \& Padovani, 2012; Crepaldi \& Hackbarth, 2002; Dib \& Abrão, 2013). Three studies also focused on important situations such as admission to pediatric intensive care (Vivian et al., 2013), preparation for inhalation (Soares \& Bomtempo, 2004) and the wait for invasive procedures (Alcântara et al., 2013).

The majority of articles relied on qualitative research designs involving descriptive or exploratory data analysis (52\%). Interviews were the most commonly used data collection technique (39\% of studies), followed by selfreport measures of stress. Though all studies discussed stress during hospitalization, few used specific instruments to evaluate stress symptoms 
Table 1

Characteristics of Brazilian Studies of Hospitalization Stress in Children Published between 2000-2016 $(N=38)$

$\begin{array}{ccc}\text { Total } & 2000-2010 & 2010-2016 \\ (N=38) n(\%) & (n=17) & (n=21)\end{array}$

Region of the country

Southeast

$18(47)$

South

$14(36)$

7

Northeast

$5(13)$

5

Authors' area of expertise

Nursing

$21(55)$

9

Psychology

$17(44)$

11

Data collection site

Teaching hospital

$16(42)$

$12(31)$

9

Hospitals specialized in caring for children and adolescents

8

Topics addressed

Perceptions of the hospitalization experience

$14(36)$

$11(28)$

$7(21)$

$6(15)$

4

Intervention programs

6

Evaluation of stress symptoms and coping

Perceptions of play in the hospital setting

Participants

Patients

$22(57)$

13

$12(31)$

4 (10)

$$
3
$$

Patients and caregivers

$$
4(10)
$$

8

6

Patient age

$6 / 7$ to $11 / 12$ years

Sample size (participants)

$$
1-20
$$$$
6(15)
$$

Chronic, communicable, respiratory

Varied
Surgery
Inhalation, PICU, invasive examinations




\begin{tabular}{|c|c|c|c|}
\hline \multicolumn{4}{|l|}{ Study design } \\
\hline Qualitative & $20(52)$ & 9 & 11 \\
\hline Quantitative, descriptive & $7(18)$ & 2 & 5 \\
\hline Quantitative, correlational & $5(13)$ & 2 & 3 \\
\hline \multicolumn{4}{|l|}{ Data collection techniques } \\
\hline Interview & $15(39)$ & 8 & 7 \\
\hline Self-report instrument: depression, stress, coping & $13(34)$ & 6 & 7 \\
\hline Story Drawing & $6(15)$ & & \\
\hline Behavior Observation & $5(13)$ & 4 & 1 \\
\hline Participant observation, field diary & $3(7)$ & 1 & 2 \\
\hline
\end{tabular}

Note. PICU $=$ Pediatric Intensive Care Unit.

(Broering \& Crepaldi, 2011; Carnier et al., 2015; Carnier et al., 2012; Matsuda-Castro \& Linhares, 2014) or distress behaviors (Soares \& Bomtempo, 2004). Other studies investigated stress through drawing techniques $(n=5)$ or observation $(n=8$; Table 1$)$.

The comparison of articles published in 2000-2010 and 2011-2016 revealed a significant shift in focus. The period from 2011-2016 saw an increase in studies from Northeastern Brazil, investigations conducted in specialized pediatric units, studies with a focus on stress symptoms and play techniques, studies involving caregivers, studies in the field of psychology, and samples of at least 50 participants (Table 1).

Twenty of the 38 studies (52\%) mentioned the theme of stress when justifying their investigation or discussing their findings. The topic was often explored in Results sections as authors discussed the contents of interviews $(26 \%)$, self-report instruments $(10 \%)$ or interaction logs $(5 \%)$.

Studies involving pre- and post-intervention comparisons evaluated programs with a focus on psychological preparation for surgery (Broering \& Crepaldi, 2011), inhalation (Soares \& Bomtempo, 2004), art therapy (Valladares \& Carvalho, 2006), and play therapy to improve coping in children (Motta \& Enumo, 2010). Other hospital-based interventions were only evaluated in terms of their overall results and the impressions of users. Positive results were reported for the following initiatives: interventions in waiting rooms prior to invasive oncological procedures (Alcântara et al., 2013); use of drawing as a mediator in presurgical patients (Dib \& Abrão, 2013); play techniques in nursing care (Jansen et al., 2010); clown care for hospitalized children (Lima, Azevedo, Nascimento, \& Rocha, 2009); use of a toy library as a developmental stimulus (Nicolino, Barbieri, Tacla, \& Ferrari, 2015); play therapy for depressive symptoms (Sanchez \& Ebeling, 2011); and group psychological intervention for parents of children in a Pediatric Intensive Care Unit (PICU; Vivian et al., 2013).

The findings of these studies were classified according to the following themes: stressful situations and emotional or behavioral reactions in patients and caregivers, and topics for hospitalbased interventions. Each of these themes will be discussed in the following sections.

\section{Stressful Situations, Emotional and Behavioral Reactions in Patients}

The distance from friends and recreational activities, unplanned or prolonged hospital stays, communication problems and restrictions, and unfamiliarity with hospital procedures can all be potential stressors (Lapa \& Souza, 2011; Menossi \& Lima, 2000; Ribeiro \& Angelo, 2005). The loss of autonomy as result of illness and organizational limitations (Lapa \& Souza, 2011) can also exacerbate any existing stress. 
Table 2

Hospital-Based Interventions for Stress among Children, as Described by Brazilian Studies Published between 2000-2016 $(N=38)$

\begin{tabular}{|c|c|c|c|c|c|}
\hline Authors & \multicolumn{2}{|c|}{ Participants/Characteristics } & Focus & Interventions & Conclusions \\
\hline $\begin{array}{l}\text { Broering } \\
\text { \& Crepaldi } \\
(2011)\end{array}$ & $\begin{array}{l}30 \text { children } \\
(6-12 \text { years })\end{array}$ & $\begin{array}{l}\text { Undergoing } \\
\text { minor surgery. }\end{array}$ & $\begin{array}{l}\text { Stress-focused } \\
\text { presurgical } \\
\text { preparation. }\end{array}$ & $\begin{array}{l}\text { (1) verbal information } \\
\text { about the surgery; }(2) \\
\text { information about the } \\
\text { surgery and hands-on } \\
\text { materials kit. }\end{array}$ & $\begin{array}{l}\text { Reduction in stress } \\
\text { levels, no difference } \\
\text { between programs. }\end{array}$ \\
\hline $\begin{array}{l}\text { Motta \& } \\
\text { Enumo } \\
(2010)\end{array}$ & $\begin{array}{l}12 \text { children } \\
\text { ( } 7-12 \text { years })\end{array}$ & $\begin{array}{l}\text { Admitted } \\
\text { to Oncology } \\
\text { Ward. }\end{array}$ & $\begin{array}{l}\text { Effects of } \\
\text { play-based } \\
\text { psychological } \\
\text { intervention. }\end{array}$ & $\begin{array}{l}\text { Identification of } \\
\text { feelings, distraction, } \\
\text { information, cognitive } \\
\text { restructuring. }\end{array}$ & $\begin{array}{l}\text { Decrease in } \\
\text { non-facilitating } \\
\text { behaviors. }\end{array}$ \\
\hline $\begin{array}{l}\text { Valladares } \\
\text { \& Carvalho } \\
(2006)\end{array}$ & $\begin{array}{l}20 \text { children } \\
(7-10 \text { years })\end{array}$ & $\begin{array}{l}\text { Children with } \\
\text { contagious } \\
\text { illnesses. }\end{array}$ & $\begin{array}{l}\text { Behavior after } \\
\text { art therapy } \\
\text { intervention. }\end{array}$ & $\begin{array}{l}\text { Artistic techniques: } \\
\text { drawing, painting, } \\
\text { collage/cut-outs, } \\
\text { sculpting, craftwork. }\end{array}$ & $\begin{array}{l}\text { Calmer, more } \\
\text { reflexive, dynamic, } \\
\text { focused } \\
\text { and participative. }\end{array}$ \\
\hline $\begin{array}{l}\text { Soares \& } \\
\text { Bomtempo } \\
(2004)\end{array}$ & $\begin{array}{l}20 \text { children } \\
(5-8 \text { years })\end{array}$ & $\begin{array}{l}\text { Exposure to } \\
\text { inhalation } \\
\text { procedures. }\end{array}$ & $\begin{array}{l}\text { Compliant and } \\
\text { noncompliant } \\
\text { behavior. }\end{array}$ & $\begin{array}{l}\text { Reading, role-play, } \\
\text { relaxation and } \\
\text { imagination. }\end{array}$ & $\begin{array}{c}\text { More adaptive } \\
\text { behavior patterns. }\end{array}$ \\
\hline $\begin{array}{c}\text { Nicolino } \\
\text { et al. }(2015)\end{array}$ & 8 relatives & $\begin{array}{c}\text { Children in } \\
\text { pediatric care. }\end{array}$ & $\begin{array}{c}\text { Perceptions } \\
\text { of story-telling. }\end{array}$ & $\begin{array}{c}\text { One hour of } \\
\text { story-telling - stories } \\
\text { selected by interns } \\
\text { and patients. }\end{array}$ & $\begin{array}{l}\text { Promotes happiness } \\
\text { and imagination, } \\
\text { reduces stress } \\
\text { and pain. }\end{array}$ \\
\hline $\begin{array}{c}\text { Alcântara } \\
\text { et al. (2013) }\end{array}$ & $\begin{array}{l}\text { Children } \\
\text { (3-11 years), } \\
\text { and Relatives; } \\
505 \text { sessions }\end{array}$ & $\begin{array}{l}\text { Waiting for } \\
\text { invasive } \\
\text { oncological } \\
\text { procedures. }\end{array}$ & $\begin{array}{l}\text { Identifying } \\
\text { needs in order } \\
\text { to reduce } \\
\text { anxiety. }\end{array}$ & $\begin{array}{l}\text { Waiting room: } \\
\text { emotional support, } \\
\text { listening, support, } \\
\text { care and entertainment. }\end{array}$ & $\begin{array}{l}\text { Play-based } \\
\text { interventions, listening } \\
\text { and psychoeducation } \\
\text { were most successful. }\end{array}$ \\
\hline $\begin{array}{c}\text { Dib \& Abrão } \\
\text { (2013) }\end{array}$ & $\begin{array}{c}1 \text { child } \\
\text { (5 years). }\end{array}$ & $\begin{array}{l}\text { Presurgical } \\
\text { admission for } \\
\text { orthopedic } \\
\text { procedure. }\end{array}$ & $\begin{array}{c}\text { Drawing in } \\
\text { presurgical care. }\end{array}$ & $\begin{array}{l}\text { Patient produced } \\
\text { seven drawings. }\end{array}$ & $\begin{array}{c}\text { Concerns were } \\
\text { identified and } \\
\text { an attempt at } \\
\text { elaboration was made. }\end{array}$ \\
\hline $\begin{array}{l}\text { Vivian et al. } \\
\text { (2013) }\end{array}$ & $\begin{array}{l}57 \text { parents } \\
\text { and relatives }\end{array}$ & $\begin{array}{l}\text { Children } \\
\text { in PICU. }\end{array}$ & $\begin{array}{l}\text { Group sessions } \\
\text { with parents } \\
\text { and caregivers. }\end{array}$ & $\begin{array}{l}\text { Topics: impact } \\
\text { of hospitalization } \\
\text { on interaction. }\end{array}$ & $\begin{array}{l}\text { Exchange of } \\
\text { experiences and } \\
\text { information. }\end{array}$ \\
\hline $\begin{array}{l}\text { Sanchez } \\
\& \text { Ebeling } \\
(2011)\end{array}$ & $\begin{array}{l}10 \text { children } \\
(7-12 \text { years })\end{array}$ & $\begin{array}{c}\text { Admitted to } \\
\text { pediatric units. }\end{array}$ & $\begin{array}{l}\text { Play-based } \\
\text { intervention } \\
\text { to decrease } \\
\text { depression. }\end{array}$ & Directed play. & $\begin{array}{l}\text { All participants } \\
\text { reported feeling } \\
\text { happy after the } \\
\text { intervention }\end{array}$ \\
\hline $\begin{array}{l}\text { Jansen et al. } \\
\text { (2010) }\end{array}$ & $\begin{array}{c}3 \text { children } \\
(5+\text { years }) \text { and } \\
7 \text { mothers }\end{array}$ & $\begin{array}{l}\text { Hospitalized } \\
\text { children. }\end{array}$ & $\begin{array}{c}\text { Benefits } \\
\text { of play } \\
\text { in nursing care. }\end{array}$ & $\begin{array}{l}\text { Nursing care combined } \\
\text { with the use of } \\
\text { instructional toys. }\end{array}$ & $\begin{array}{l}\text { Acceptance } \\
\text { of procedures, } \\
\text { participation, } \\
\text { reduced stress. }\end{array}$ \\
\hline $\begin{array}{l}\text { Lima et al. } \\
\text { (2009) }\end{array}$ & 20 children & $\begin{array}{c}\text { Admitted to } \\
\text { pediatric units. }\end{array}$ & $\begin{array}{l}\text { Clown care for } \\
\text { hospitalized } \\
\text { children. }\end{array}$ & $\begin{array}{l}\text { Forms of expression: } \\
\text { music, acting, children's } \\
\text { books and magic. }\end{array}$ & $\begin{array}{l}\text { Imagination, } \\
\text { happiness, control } \\
\text { over daily routine; } \\
\text { focus on needs. }\end{array}$ \\
\hline
\end{tabular}

Note. PICU $=$ Pediatric Intensive Care Unit. 
The inflexibility of the health care team and the provision of insensitive and unsympathetic care (Silva \& Ribeiro, 2000) can contribute to this situation.

Children's reactions to hospitalization may include moodiness, fear, trouble eating or sleeping, worry, insecurity, apathy, agitation, anxiety, sadness and guilt (Crepaldi \& Hackbarth, 2002; Dib \& Abrão, 2013; Hostert et al., 2014; Ribeiro \& Pinto, 2009; Sanchez \& Ebeling, 2011). Fear is often caused by pain (Silva \& Ribeiro, 2000), which is in turn correlated with symptoms of stress (MatsudaCastro \& Linhares, 2014). Children may also worry about being abandoned, or concerned for the well-being of their mothers, who may be placed in uncomfortable accommodations or exposed to the threat of unemployment (Lapa \& Souza, 2011). The suffering associated with maternal absence may be even greater than that associated with the physical pain resulting from invasive medical procedures (Dias et al., 2013).

Invasive procedures and changes in the daily routine may be associated with coping strategies which interfere with treatment adherence and the adaptation to the hospital environment (Moraes \& Enumo, 2008; Motta \& Enumo, 2004b). Carnier et al. (2015) found that coping strategies may vary according to age, gender, prior experience with surgery and caregiver stress. It is important to note that in some cases, children may come to associate the hospital with exclusion, fear, suffering or punishment. However, they may also associate it with help, treatment or support, depending on the image and social representation of the institution (Ribeiro $\&$ Pinto, 2009). The opinions or suggestions of caregivers, and the perceived protection offered by hospital staff may all lead children to exhibit more positive reactions (Silva \& Ribeiro, 2000). Therefore, though individuals may experience some anxiety as result of changes in setting, exposure to unfamiliar people and the possibility of painful procedures, the hospital may also be perceived as a place to get well (Ferreira et al., 2014), and receive exclusive maternal care, food, toys and other forms of compensation (Lapa \& Souza, 2011).

\section{Stressful Situations, Emotional and Behavioral Reactions in Caregivers}

Families may face several difficulties during the hospitalization of a child or adolescent. Examples include leaving the domestic environment, worrying about new responsibilities, problems with accommodations and managing unhelpful visitation schedules, in addition to insufficient attention from health care workers (Milanesi, Collet, Oliveira, \& Vieira, 2006; Siqueira, Sigaud, \& Rezende, 2002). Individuals may also experience a lack of affectionate care, excessive bureaucracy with a focus on institutional demands rather than patient needs, and a loss of autonomy (Xavier et al., 2014). The need to care for other offspring may also cause feelings of suffering and impotence (Rumor \& Boehs, 2013; Siqueira et al., 2002). Additional difficulties reported by family members include problems with hospital infrastructure, an unpredictable daily routine, tiredness, guilt for the illness and the lack of individualized care (Rumor \& Boehs, 2013). Medical procedures, especially firsttime surgery, may also increase stress (Carnier et al., 2012). The suffering of caregivers may be exacerbated by an insufficient response from health professionals (Rodrigues, Amador, Silva, Reichert, \& Collet, 2013), the neglect of the caregiver's right to receive orientation (Milanesi et al., 2006) and even excessively technical language (Figueiredo, Gomes, Pennafort, Monteiro, \& Figueiredo, 2013).

The articles reviewed identified stress symptoms in $70 \%$ to $80 \%$ of interviewed mothers (Carnier et al., 2015; Carnier et al., 2012; Matsuda-Castro \& Linhares, 2014). Most participants in these samples were in the Resistance stage of stress - where the body tries to return to equilibrium after coming into contact with a stressor, and manifests stress symptoms as they try to adapt to the problem or eliminate it - with a predominance of psychological symptoms. Reactions experienced by these individuals include anxiety, suffering, exhaustion, nervousness and impatience, which may make it difficult to accompany a child during hospitalization, especially when the 
individual lacks the internal resources to deal with the situation or an opportunity to express them (Costa, Mombelli, \& Marcon, 2009; Milanesi et al., 2006).

When faced with these conditions, relatives may either give in or resort to transgression, ignoring or bypassing regulations as a form of resistance and search of liberty (Xavier et al., 2014). In order to deal with the changes brought about by treatment, they also attempt to restructure roles and review priorities, in addition to seeking predictability, regularity and organized environments (Rumor \& Boehs, 2013). The time to diagnosis may be an important factor in this process. Carnier et al. (2015), for instance, found a higher prevalence of stress in the caregivers of children in first-time surgery rather than those with chronic illnesses, since the former have had less time to adapt to the diagnosis and treatment.

\section{Action and Intervention in the Hospital Environment}

The studies identified a need for initiatives which could improve care and attend to the needs of families and patients, offer support in the form of psychological techniques, and encourage the use of play techniques during hospitalization. The interaction with health professionals may decrease suffering and loneliness, while increasing feelings of familiarity and security. Silva and Ribeiro (2000) note that children value attentive care and associate it with security and availability. They also underscore the importance of engaging the family and child in their daily care, explaining procedures, attending to reactions including fear and crying, and valuing their opinions and suggestions as pertains to the satisfaction of their needs, which can provide a sense of control over oneself and the environment.

The needs of the families should therefore be considered in order to increase well-being during treatment. Xavier et al. (2014) suggests that regulations be made more flexible so as to account for the needs of families, in accordance with the principles of humanized care and respect of individual differences. Milanesi et al. (2006) also emphasize the importance of humanized care and attending to the feelings of patients and relatives. The parental interventions proposed by Vivian et al. (2013), for instance, led to an increased perception of care, which can contribute to the collaboration between health professionals and patients. Figueiredo et al. (2013) highlighted the importance of the therapeutic bond in establishing trust and tranquility in mothers.

Feelings of sadness are known to decrease after hospital-based interventions, confirming the strategic role of Psychology in hospital settings (Sanchez \& Ebeling, 2011). The decrease in non-facilitating or maladaptive behaviors, such as crying, may also be greater after targeted interventions than free play in the hospital (Motta \& Enumo, 2010). Soares and Bomtempo (2004) found an increase in adaptive behaviors in their experimental group; Broering and Crepaldi (2011) identified two forms of preparation for elective surgery - provision of verbal information alone or combined with the offer of toys and entertainment resources which led to a decrease in stress.

Sanchez and Ebeling (2011) recommended the use of interventions involving free play, games, collages, drawing and stories to help children manage their anxiety and beliefs. Alcântara et al. (2013) also achieved positive results using play techniques and therapeutic listening to resignify the disease process and strengthen coping and bonding mechanisms. Valladares and Carvalho (2006) found that patients who received art therapy were more relaxed, respectful, communicative, solicitous, independent and controlled. Play techniques also led to a decrease in the levels of suffering associated with surgery (Dib \& Abrão, 2013).

The use of playful activities in hospi-tal settings should be encouraged and institutionalized, in order to attenuate difficulties, promote distraction, and provide an opportunity for relief and pleasure (Hostert et al., 2014). Motta and Enumo (2004a) found that nearly $80 \%$ of children in their sample would like to 
have the opportunity to play in the hospital. If the child is happy, they may have an easier hospitalization and a more favorable course of development (Lima et al., 2009). When listening to stories, for instance, children may feel happy, forget their daily troubles and be more likely to cooperate and engage in play activities. They may also feel less pain and show improvements in concentration, contributing to integration and promoting physical and emotional well-being, as discussed by Nicolino et al. (2015). Drawing may also be a useful mediator for communication, facilitating the expression of feelings and the psychological elaboration of fear and insecurity (Dib \& Abrão, 2013).

According to Lapa and Souza (2011), it is important for health professionals to value the use of play as a means to decrease negative feelings and ensure that patients' questions and needs are addressed. Sousa, Vitta, Lima, and Vitta (2015) found that play can modify the child's environment, provide opportunities for care and lessen the traumatic nature of the hospital experience, improving individuals' comprehension of hospital procedures. According to Motta and Enumo (2004b), play encourages the interaction with health professionals, the verbalization of feelings and the acceptability of procedures, leading to positive effects on coping and the approximation between the hospital environment and the child's daily routine.

Play can also have positive effects on the body and on psychosomatic equilibrium, reducing tension and encouraging autonomy, even during hospitalization. Jansen et al. (2010) report that, according to patients' parents, the use of play in hospital care demonstrates affection and respect, decreases the hostility of the environment and encourages physical activity. Lapa and Souza (2011) found that playing allows children to become active agents in the situation, with several even incorporating medical procedures into pretend play. Recreational activities change the focus of the hospital routine and increase the attention paid to the child, allowing them to express their needs, conclusions and knowledge about the disease and its treatment (Lima et al., 2009).

\section{Discussion}

This study reviewed the national literature on stress indicators in patients and families during hospitalization. Studies published over the past 16 years (2000-2016) were analyzed in terms of their methodological characteristics, contributions to the literature, and suggestions for intervention.

The results highlighted a need for additional investigations of the direct and indirect relationships between stress and hospitalization, since only 38 studies were found to deal with these issues. Additionally, the majority of studies recruited samples from Southern, Northeastern and Southeastern Brazil, so that further investigation is needed into the remaining parts of the country.

Only four studies evaluated the perspectives of more than one group of participants. Such studies could contribute to the comprehension of coping processes in patients, families and health professionals, especially the way in which these responses manifest and co-regulate (Compas, Jaser, Dunn, \& Rodriguez, 2012; Skinner \& Zimmer-Gembeck, 2016).

Another important methodological characteristic found in the majority of studies was the reliance on samples with varying clinical conditions. Such samples may only be able to provide general information about the hospitalization process. Additionally, patients submitted to major procedures, such as admission to PICU, preparation for inhalation, and invasive examinations were only briefly discussed. Though some studies focused on specific procedures or health conditions in order to define a research question, most investigations involved heterogeneous samples. This underscores the need for additional studies of specific health issues and medical procedures. This would allow for the identification of similarities and differences between these situations, making for more effective interventions.

Few studies sought to evaluate stress based on its symptoms. Many assessed this construct through drawing, observation and, especially, interviews. Few investigations about stress 
symptomatology or the qualitative nature of its indicators were identified. However, it must be noted that stress was not the primary target of some investigations, who only discussed this construct as a secondary outcome. Though the choice to include such studies in the review may be considered a limitation of the present study, it allowed for a more comprehensive assessment of potential stressors and reactions associated with hospitalization.

It may be important for future studies to conduct similar investigations in different databases, and extend the search to theses and dissertations. Comparisons of the national and international literature on this topic of study may also prove useful.

The way stress was conceptualized and defined in the articles reviewed indicates a need for caution when applying this construct to the context of hospitalization, or even when formulating research questions and discussing its association with medical procedures. Researchers should be especially careful in interpreting the meaning of 'stress' when the term is encountered in participants' speech, since it may be used inadvertently or with a common-sense connotation. This will prevent the dissemination of conclusions based on inaccurate evidence (Aldwin, 2011).

Nevertheless, the distance from friends and recreational activities, unplanned or prolonged hospitalization, communication issues and lack of knowledge about procedures, especially in situations where individuals have little autonomy, may all be potential stressors for some children (Lapa \& Souza, 2011; Menossi \& Lima, 2000; Ribeiro \& Angelo, 2005; Silva \& Ribeiro, 2000). Several studies also mentioned concerns about maternal wellbeing and a fear of abandonment (Dias et al., 2013; Lapa \& Souza, 2011; Matsuda-Castro \& Linhares, 2014; Silva \& Ribeiro, 2000). Health professionals must pay special attention to these issues.

The literature also proposed interventions, many with evidence of positive results. However, the lack of detailed descriptions and evaluations precluded a more thorough discussion of these findings in the present review. The use of play techniques, however, was cited, analyzed and emphasized by several studies, cementing its status as an important contributor to the quality of life of patients and their families in the hospital setting.

In some cases, children may come to associate the hospital with exclusion, fear and punishment, or alternatively, with help, treatment and support, depending on the image associated with the institution (Ribeiro \& Pinto, 2009). These differences indicate a need for additional research into the process of coping, so that the risk and protective factors associated with this situation can be better understood (Carona et al., 2014; Compas et al., 2012; Motta et al., 2015). There is also a need for studies with larger samples, which evaluate the interaction between multiple variables, such as stress symptoms and features of the disease, treatment, patients, relatives and professionals, in addition to coping behaviors, perceptions and beliefs about hospitalization and illness, previous hospital experience and length of hospital stay.

The studies reviewed also identified a need for additional attention to caregivers. Reactions such as exhaustion, nervousness and impatience (Milanesi et al., 2006) may make the hospital stay more difficult, especially when individuals do not have the internal resources to deal with the situation or the opportunity to express them (Costa et al., 2009). Since the reaction of each person may influence and be influenced by the context and those around them, as per the transactional nature of stress and coping processes in adversity, these reactions may develop a circular pattern which aggravates the suffering of patients and other participants of the situation (Aldwin, 2011; Lansing \& Berg, 2014; Skinner \& Zimmer-Gembeck, 2016; Vivian et al., 2013). The family relationship between patient and caregiver, and its degree of trust, affection and security, in addition to the possibility of alternating with other caregivers, must also be analyzed in terms of their potential influence on health outcomes. 


\section{Final Considerations}

This literature review identified the need for studies which take the necessary care in interpreting the use of the term "stress" in the context of hospitalization, in order to analyze this construct from the perspective of different participants in the situation and evaluate larger samples. There is also a need for additional studies of specific symptoms, conditions and medical procedures. These observations may contribute to the comprehension of the coping process among patients and relatives, and help define intervention strategies, which should follow a contextual or ecological approach, considering the complexity of the settings where the health-illness process unfolds, including the family, schools and the community.

\section{References}

*Alcântara, T. V., Shioga, J. E. M., Lima, M. J. V., Lage, A. M. V., \& Maia, A. H. N. (2013). Intervenções psicológicas na sala de espera: Estratégias no contexto da Oncologia Pediátrica [Psychological intervention in the waiting room: Strategies in the context of Pediatric Oncology]. Revista da Sociedade Brasileira de Psicologia Hospitalar, 16(2), 103-119. Retrieved from http://pepsic.bvsalud.org/pdf/rsbph/v16n2/ v16n2a08.pdf

Aldwin, C. M. (2011). Stress and coping across the lifespan. In S. Folkman (Ed.), The Oxford Handbook of Stress, Health, and Coping (pp. 15-84). New York: Oxford University Press.

Branco, M. S. S., \& Linhares, M. B. M. (2018). The toxic stress and its impact on development in the Shonkoff's Ecobiodevelopmental Theorical approach. Estudos de Psicologia (Campinas), 35(1), 89-98. doi: 10.1590/198202752018000100009

*Broering, C. V., \& Crepaldi, M. A. (2011). Preparação psicológica e o estresse de crianças submetidas a cirurgias [Psychological preparation and stress of children undergoing surgery]. Psicologia em Estudo, 16(1), 15-23. doi: 10.1590/S141373722011000100003

*Carnier, L. E., Padovani, F. H. P., Perosa, G. B., \& Rodrigues, O. M. P. R. (2015). Estratégias de enfrentamento em crianças em situação pré- cirúrgica: Relação com idade, sexo, experiência com cirurgia e estresse [Coping strategies among children in a pre-surgical situation: Relationship with age, gender, experience with surgery and stress]. Estudos de Psicologia (Campinas), 32(2), 319-330. doi: 10.1590/ S1414-98932007000300003

*Carnier, L. E., Rodrigues, O. M. P. R., \& Padovani, F. H. P. (2012). Stress materno e hospitalização infantil pré-cirúrgica [Maternal stress and presurgical infant hospitalization]. Estudos de Psicologia (Campinas), 29(3), 315-325. doi: 10.1590/S0103-166X2012000300002

Carona, C., Silva, N., Moreira, H., Barros, L., \& Canavarro, M. C. (2014). Pediatric health-related stress, coping and quality of life. Paediatrics Today, 10(2), 112-128. doi: 10.5457/p2005114.97

Compas, B. E., Jaser, S. S., Dunn, M. J., \& Rodriguez, E. M. (2012). Coping with chronic illness in childhood and adolescence. Annual Review of Clinical Psychology, 27(8), 455-480. doi: 10.1146/annurev-clinpsy-032511-143108

*Costa, J. B., Mombelli, M. A., \& Marcon, S. S. (2009). Avaliação do sofrimento psíquico da mãe acompanhante em alojamento conjunto pediátrico [Evaluation of the psychological suffering of the mother who rooms in with her child at a pediatric hospital]. Estudos de Psicologia (Campinas), 26(3), 317-325. doi: 10.1590/S0103-166X2009000300005

*Crepaldi, M. A., \& Hackbarth, I. D. (2002). Aspectos psicológicos de crianças hospitalizadas em situação pré-cirúrgica [Psychological aspects of the hospitalized children in the pre-surgery situation]. Temas em Psicologia, 10(2), 99-111. Retrieved from http://pepsic.bvsalud.org/pdf/tp/ v10n2/v10n2a02.pdf

*Dias, J. J., Silva, A. P. C., Freire, R. L. S., \& Andrade, A. S. A. (2013). A experiência de crianças com câncer no processo de hospitalização e no brincar [Experience of children with cancer and the importance of recreational activities during hospitalization]. Revista Mineira de Enfermagem, 17(3), 608-613. Retrieved from http://www.reme.org.br/exportar-pdf/676/ v17n3a10.pdf

*Dib, E. P., \& Abrão, J. L. F. (2013). Uma experiência terapêutica pré-cirúrgica: $\mathrm{O}$ uso do desenho como mediador lúdico [A pre-surgical therapeutic experience: The use of drawing as 
mediator]. Boletim de Psicologia, 63(139), 159174. Retrieved from http://pepsic.bvsalud.org/ pdf/bolpsi/v63n139/v63n139a05.pdf

*Ferreira, N. A. S., Esmeraldo, J. D., Blake, M. T., Antão, J. Y. F. L., Raimundo, R. D., \& Abreu, L. C. (2014). Representação social do lúdico no hospital: O olhar da criança [Social representation of the hospital ludic: Look of the child]. Revista Brasileira de Crescimento e Desenvolvimento Humano, 24(2), 188-194. Retrieved from http://pepsic.bvsalud.org/pdf/ $\mathrm{rbcdh} / \mathrm{v} 24 \mathrm{n} 2 / \mathrm{pt}$ 11.pdf

*Figueiredo, S. V., Gomes, I. L. V., Pennafort, V. P. S., Monteiro, A. R. M., \& Figueiredo, J. V. (2013). Comunicação terapêutica entre profissionais de saúde e mães acompanhantes durante a hospitalização do filho [Therapeutic communication between health professionals and mothers accompanying children during inpatient treatment]. Escola Anna Nery Revisa de Enfermagem, 17(4), 690-697. doi: $10.5935 / 1414-8145.20130013$

Gomes, G. L. L., Fernandes, M. G. M., \& Nóbrega, M. M. L. (2016). Ansiedade da hospitalização em crianças: Análise conceitual [Hospitalization anxiety in children: conceptual analysis]. Revista Brasileira de Enfermagem, 69(5), 884889. doi: 10.1590/0034-7167-2015-0116

Grant, K. E., Compas, B. E., Stuhlmacher, A. F., Thurm, A. E., McMahon, S. D., \& Halpert, J. A. (2003). Stressors and child and adolescent psychopathology: Moving from markers to mechanisms of risk. Psychological Bulletin, 129, 447-466. doi: 10.1037/0033-2909.129.3.447

*Hostert, P. C. C. P., Enumo, S. R. F., \& Loss, A. B. M. (2014). Brincar e problemas de comportamento de crianças com câncer de classes hospitalares [Playing and behavior problems of children with cancer at a hospital classroom]. Psicologia: Teoria e Prática, 16(1), 127-140. http://dx.doi.org/10.15348/1980-6906/ psicologia.v16n1p127-140

*Hostert, P. C. C. P., Motta, A. B., \& Enumo, S. R. F. (2015). Coping da hospitalização em crianças com câncer: A importância da classe hospitalar [Coping with hospitalization in children with cancer: The importance of the hospital school]. Estudos de Psicologia (Campinas), 32(4), $627-$ 639. doi: 10.1590/0103-166X2015000400006

*Jansen, M. F., Santos, R. M., \& Favero, L. (2010). Benefícios da utilização do brinquedo durante o cuidado de enfermagem prestado a criança hospitalizada [Benefits from the use of toys during nursing care delivered to hospitalized children]. Revista Gaúcha de Enfermagem, 31(2), 247253. doi: 10.1590/S1983-14472010000200007

Kieling, C., Baker-Henningham, H., Belfer, M., Conti, G., Ertem, I., Omigbodun, O., ... Rahman, A. (2011). Child and adolescent mental health worldwide: Evidence for action. Lancet, 378, 1515-1525. doi: 10.1016/S01406736(11)60827-1

Lansing, A. H., \& Berg, C. A. (2014). Topical review: Adolescent self-regulation as a foundation for chronic illness self-management. Journal of Pediatric Psychology, 39(10), 1091-1096. doi: 10.1093/jpepsy/jsu067

*Lapa, D. F., \& Souza, T. V. (2011). A percepção do escolar sobre a hospitalização: Contribuições para o cuidado de enfermagem [Scholars' perception about hospitalization: Contributions for nursing care]. Revista da Escola de Enfermagem, USP, 45(4), 811-817. doi: 10.1590/S0080-62342011000400003

*Lima, R. A. G., Azevedo, E. F., Nascimento, L. C., \& Rocha, S. M. M. (2009). A arte do teatro Clown no cuidado às crianças hospitalizadas [The art of Clown theater in care for hospitalized children]. Revista da Escola de Enfermagem USP, 43(1), 186-193. doi: 10.1590/S008062342009000100024

Linhares, M. B. M. (2016). Estresse precoce no desenvolvimento: Impactos na saúde e mecanismos de proteção [Early childhood stress: Impacts on health and protective mechanisms]. Estudos de Psicologia (Campinas), 33(4), 587-599. doi: 10.1590/198202752016000400003

*Matsuda-Castro, A. C., \& Linhares, M. B. M. (2014). Dor e estresse em crianças hospitalizadas na percepção das crianças e das mães [Pain and Distress in Inpatient Children According to Child and Mother Perceptions]. Paidéia (Ribeirão Preto), 24(59), 351-359. doi: 10.1590/198243272459201409

*Menossi, M. J., \& Lima, R. A. G. (2000). A problemática do sofrimento: Percepção do adolescente com câncer [The problem of suffering: Perceptions by adolescents with cancer]. Revista da Escola de Enfermagem USP, 34(1), 45-51. doi: 10.1590/S008062342000000100006 
*Milanesi, K., Collet, N., Oliveira, B. R. G., \& Vieira, C. S. (2006). Sofrimento psíquico da família de crianças hospitalizadas [Psychological suffering of the families of hospitalized chidren]. Revista Brasileira de Enfermagem, 59(6), 769-774. doi: 10.1590/S0034-71672006000600009

Miller, G. E., Chen, E., \& Parker, K. J. (2011). Psychological stress in childhood and susceptibility to the chronic diseases of aging: Moving towards a model of behavioral and biological mechanisms. Psychological Bulletin, 137(6), 959-997. doi: 10.1037/a0024768.

*Moraes, E. O., \& Enumo, S. R. F. (2008). Estratégias de enfrentamento da hospitalização em crianças avaliadas por instrumento informatizado [Coping to hospitalization in children assessed by IT-based instrument]. Psico USF, 13(2), 221231. doi: 10.1590/S1413-82712008000200009

*Motta, A. B., \& Enumo, S. R. F. (2004a). Brincar no hospital: Estratégia de enfrentamento da hospitalização infantil [Playing in the hospital: Coping strategy in child hospitalization]. Psicologia em Estudo, 9(1), 19-28. doi: 10.1590/ S1413-73722004000100004

*Motta, A. B., \& Enumo, S. R. F. (2004b) Câncer infantil: Uma proposta de avaliação as estratégias de enfrentamento da hospitalização [Childhood cancer: An assessment of hospitalization coping strategies proposal]. Estudos de Psicologia (Campinas), 21(3), 193-202. doi: 10.1590/ S0103-166X2004000300004

*Motta, A. B., \& Enumo, S. R. F. (2010). Intervenção psicológica lúdica para o enfrentamento da hospitalização em crianças com câncer [Recreational psychological intervention for coping with hospitalization in children with cancer]. Psicologia Teoria e Pesquisa, 26(3), 445454. doi: 10.1590/S0102-37722010000300007

Motta, A. B., Perosa, G. B., Barros, L., Silveira, K. A., Lima, A. S., Carnier, L. E., Hostert, P. C. C. P., \& Caprini, F. R. (2015). Comportamentos de coping no contexto da hospitalização infantil [Coping behaviors in the child hospitalization context]. Estudos de Psicologia (Campinas), 32(2), 331-341. doi: 10.1590/0103166X2015000200016

*Nicolino, T. N. A., Barbieri, M. C., Tacla, M. T. G. M., \& Ferrari, R. A. P. (2015). Contação de história na unidade pediátrica: Percepção de acompanhantes de crianças hospitalizadas
[Storytelling in the pediatric unit: Perception of persons accompanying hospitalized children]. Revista de Enfermagem UFSM, 5(1), 32-39. doi: $10.5902 / 2179769213204$

Pinquart, M., \& Shen, Y. (2011). Behavior problems in children and adolescents with chronic physical illness: A meta-analysis. Journal of Pediatric Psychology, 36(9), 1003-1016. doi: 10.1093/ jpepsy/jsr042

Pinquart, M., \& Teubert, D. (2012). Academic, physical, and social functioning of children and adolescents with chronic physical illness: A meta-analysis. Journal of Pediatric Psychology, 37(4), 376-389. doi: 10.1093/jpepsy/jsr106

Price, J., Kassam-Adams, N., Alderfer, M. A., Christofferson, J., \& Kazak, A. E. (2016). Systematic review: A reevaluation and update of the Integrative (Trajectory) Model of Pediatric Medical Traumatic Stress. Journal of Pediatric Psychology, 41(1), 86-97. doi: 10.1093/jpepsy/ jsv074

*Ribeiro, C. A., \& Angelo, M. (2005). O significado da hospitalização para a criança pré-escolar: Um modelo teórico. [The meaning of hospitalization for the pre-school child: A theoretical model]. Revista da Escola de Enfermagem USP, 39(4), 391-400. doi: 10.1590/S008062342005000400004

*Ribeiro, C. R., \& Pinto, A. A., Jr. (2009). A representação social da criança hospitalizada: Um estudo por meio do procedimento de desenho-estória com tema. Revista da Sociedade Brasileira de Psicologia Hospitalar, 12(1), 3156. Retrieved from http://pepsic.bvsalud.org/ $\mathrm{pdf} / \mathrm{rsbph} / \mathrm{v} 12 \mathrm{n} 1 / \mathrm{v} 12 \mathrm{n} 1 \mathrm{a} 04 . \mathrm{pdf}$

*Rodrigues, P.F., Amador, D.D., Silva, K.L., Reichert, A. P. S., \& Collet, N. (2013). Interação entre equipe de enfermagem e família na percepção dos familiares de crianças com doenças crônicas [Interaction between the nursing staff and family from the family's perspective]. Escola Anna Nery Revista de Enfermagem, 17(4), 781-787. doi: 10.5935/1414-8145.20130024

*Rumor, P. C. F., \& Boehs, A. E. (2013). O impacto da hospitalização infantil nas rotinas das famílias monoparentais. [The impact of child hospitalization on the everyday lives of single parent families]. Revista Eletrônica de Enfermagem, 15(4), 1007-1015. doi: 10.5216/ ree.v15i4.19464 
*Sanchez, M. L. M., \& Ebeling, V. L. N. (2011). Internação infantil e sintomas depressivos: Intervenção psicológica [Admission depressive symptoms and children: Psychological intervention]. Revista da Sociedade Brasileira de Psicologia Hospitalar, 14(1), 186-199. Retrieved from http://pepsic.bvsalud.org/pdf/ $\mathrm{rsbph} / \mathrm{v} 14 \mathrm{n} 1 / \mathrm{v} 14 \mathrm{n} 1 \mathrm{a} 11 . \mathrm{pdf}$

*Silva, C. C., \& Ribeiro, N. R. R. (2000). Percepções da criança acerca do cuidado recebido durante a hospitalização [Children's perception regarding the care received during hospitalization]. Revista Brasileira de Enfermagem, 53(2), 311-323. doi: 10.1590/S0034-71672000000200017

*Siqueira, L. S., Sigaud, C. H. S., \& Rezende, M. A. (2002). Fatores que apoiam e não apoiam a permanência de mães acompanhantes em unidade de pediatria hospitalar. [Factors that support and don't support the permanence of accompanying mothers in a hospital pediatric unit]. Revista da Escola de Enfermagem USP, 36(3), 270-275. doi: 10.1590/S0080-6234200200030000

Skinner, E. A., \& Zimmer-Gembeck, M. J. (2016). The development of coping: Stress, neurophysiology, social relationships, and resilience during childhood and adolescence. doi: 10.1007/978-3319-41740-0

Slavich, G. M., \& Cole, S.W. (2013). The emerging field of Human Social Genomics. Clinical Psychological Science, 1(3), 331-334.

*Soares, M. R. Z., \& Bomtempo, E. (2004). A criança hospitalizada: Análise de um programa de atividades preparatórias para o procedimento médico de inalação [The hospitalized child: An analysis of a psychological intervention program on the preparation for an inhalation medical procedure]. Estudos de Psicologia (Campinas), 21(1), 53-64. doi: 10.1590/S0103166X2004000100005
*Sousa, L. C., Vitta, A., Lima, J. M., \& Vitta, F. C. F. (2015). O brincar no contexto hospitalar na visão dos acompanhantes de crianças internadas [The act of playing within the hospital context in the vision of the accompanying persons of the hospitalized children]. Revista Brasileira de Crescimento e Desenvolvimento Humano, 25(1), 41-49. doi: 10.7322/JHGD.96766

*Valladares, A. C. A., \& Carvalho, A. M. P. (2006). A arterapia e o desenvolvimento do comportamento no contexto da hospitalização [Art therapy and behavior development in the context of hospitalization]. Revista da Escola de Enfermagem, 40(3), 350-355. doi: 10.1590/ S0080-62342006000300006

*Vivian, A. G., Rocha, C. C., Agra, K. P., Krummenauer, C., Benvenutti, D. K., Timm, J. S., \& Souza, F. P. (2013). Conversando com os pais: Relato de experiência de intervenção em grupo em UTI pediátrica [Talking to parents: Experience report of group interventio in pediatrics ICU]. Aletheia, 40, 174-184. Retrieved from http://pepsic.bvsalud.org/pdf/ aletheia/n40/n40a15.pdf

*Xavier, D. M., Gomes, G. C., \& Salvador, M. S. (2014). O familiar cuidador durante a hospitalização da criança: Convivendo com normas e rotinas [The family caregiver during the hospitalization of the child: Coexisting with rules and routines]. Escola Anna Nery Revista de Enfermagem, 18(1), 68-74. doi: 10.5935/14148145.20140010
Received: 10/11/2017

$1^{a}$ revision: $25 / 06 / 2018$

Accepted: 25/06/2018

(9) (C) The Author(s), 2018. Open Access. This article is distributed under the terms of the Creative Commons Attribution 4.0 International License (http://creativecommons.org/licenses/by/4.0/), which permits unrestricted use, distribution, and reproduction in any medium, provided you give appropriate credit to the original author(s) and the source, provide a link to the Creative Commons license, and indicate if changes were made. 